\title{
Applicability of the Reference Interval and Reference Change Value of Hematological and Biochemical Biomarkers to Sport Science
}

\author{
Lázaro Alessandro Soares Nunes, Fernanda Lorenzi Lazarim, \\ René Brenzikofer and Denise Vaz Macedo \\ Laboratory of Exercise Biochemistry (LABEX), Biology Institute, \\ State University of Campinas (UNICAMP), \\ Laboratory of Instrumentation for Biomechanics, Physical Education Faculty, \\ State University of Campinas (UNICAMP), Campinas, SP, \\ Brazil
}

\section{Introduction}

The training principle states that tissue adaptation depends upon overload applications. The cumulative effect of these programmed breaks in homeostasis through variations in the intensity, duration and frequency of the exercise is higher performance. However, it is important to point out that the positive adaptive response, which is reflected by increased performance, depends upon an adequate recovery time between each training session and during training sessions to result in phenotypic alterations (Hohl et al., 2009).

Training sessions and nutrition are highly interrelated. Repeated training sessions typically require a diet that can sustain muscle energy stores to execute the training proposed. The phenotypic alterations that lead to increased performance result from an intense process of protein synthesis that occurs during the recovery period and can last up to $24 \mathrm{~h}$ after the exercise session. This process is highly influenced by food ingestion, which offers energy and nutrients that are essential to the process and to the recovery of energy reserves (Hawley et al., 2006). Recent evidence shows that some nutrients can potentiate the protein synthesis pathways that are activated by exercise, influencing the adaptive process and performance (Hawley et al., 2011).

Professional athletes, for example, soccer players, are submitted to an annual training and competition routine with periods of recovery that are not always properly adjusted to the workload. The main problem is that the current championship schedule generally does not allow the teams to take the minimum time required for appropriate physical preparation because the different stages (competitions and physical, technical and tactical training) overlap. As a consequence, the athletes may suffer an imbalance between the effort put forth and the recovery time during the competitive season, which increases the likelihood that the workload will be excessive for some players.

Each overload stress results in different degrees of microtrauma in the muscle, connective tissue, and/or bones and joints, which trigger an inflammatory response promoting repair 
and muscular regeneration. These microtraumas are therefore called adaptive microtrauma (AMT). An AMT may be regarded as an initial phase along an injury continuum. Conceivably, this injury might progress from the initial benign AMT stage to a subclinical injury in the athlete who is training strenuously and frequently (Smith, 2000). The main challenge for the better adjustment of physical training methodologies is therefore to program a sequence of exercise stimuli that has an ideal relationship between the amount of exercise and the time to recovery between sessions and that leads to increased performance with a lower energy cost. The longitudinal evaluation of some blood analytes may reveal markers of previously altered situations, which could prevent the amplification of the response before the performance is affected. A variety of studies using different types of exercise protocols have already demonstrated that biomarkers, such as creatine kinase (muscular overload), urea (protein turnover), creatinine (muscular mass), uric acid (the major antioxidant in plasma) and hematological parameters, suffer some modulation by exercise (Sawka et al., 2000; Pattwell et al., 2004; Lac \& Maso 2004; Finaud et al., 2006; Peake et al., 2007; Lippi et al., 2008; Lazarim et al., 2009). However, there is currently no consensus about the applicability of these biomarkers as markers of training effects that effectively contribute to reaching and maintaining a better performance.

\subsection{Biomarkers of training effects \\ 1.1.1 Muscular damage}

The muscle tissue may be damaged both directly and indirectly. Direct damage may be due to crush injuries (Brancaccio et al., 2010; Cervellin et al., 2010), but the main force responsible for damage is the mechanical stress that occurs during training sessions (Fielding et al., 1993; Tidball, 2005a). Indirect damage can originate from several sources that reduce membrane permeability (e.g., drugs, toxins, electrolyte alterations, bacterial or viral infections and disorders in carbohydrate metabolism) (Brancaccio et al., 2010).

Muscle damage is related to a disorganization of the myofibrillar structure and a disruption of the $\mathrm{Z}$ line, extracellular matrix, basal lamina and sarcolemma, allowing some of the proteins present within the cell to be release into the bloodstream (Sayers \& Clarkson, 2003). Among them are creatine kinase (CK), lactate dehydrogenase (LDH), aspartate aminotransferase (AST) and myoglobin. These proteins are blood markers of muscle functional status, and an increase in their serum concentrations or activities may be an index for either muscle damage or muscular adaptation to training (Brancaccio et al., 2008; Lazarim et al., 2009).

The enzyme CK is a globular protein with a molecular mass of 43-45 kDa. It influences the availability of energy to the muscles through the exchange of high-energy phosphate from phosphocreatine (PCr) to ADP (adenosine diphosphate) for fast ATP (adenosine triphosphate) production, as follows:

$$
\mathrm{PCr}+\mathrm{ADP}+\mathrm{H}^{+} \longrightarrow \mathrm{CK} \longrightarrow \mathrm{ATP}+\mathrm{Cr}
$$

Five isoforms of the enzyme are present in the skeletal muscle, cardiac muscle and brain: three of them are found in the cytoplasm (CK-MM, CK-MB and CK-BB, respectively), and two isoforms are found in the mitochondria. Because of their differential tissue distribution, they provide different information about tissue damage: CK-MM is a marker for muscle damage, CK-MB is a marker for acute myocardial infarction and CK-BB is a marker for brain damage (Brancaccio et al., 2010). 
Doubts about the application of CK analysis to the monitoring of the muscular workload in athletes are derived from studies suggesting that this analyte is an unreliable marker for histological muscle lesions (Malm, 2001). Another source of doubt is that the serum CK values measured in individuals exercising to a similar degree showed high variability and a non-Gaussian distribution (Clarkson \& Ebbeling, 1988; Lazarim et al., 2009).

Studies of subjects performing specific exercises for short, defined periods have shown that the time of CK release into the bloodstream and its clearance from the plasma depends on the training level, type, and intensity as well as the duration of the exercise. Peak serum CK values of approximately twice the baseline levels occur eight hours after strength training (Serrão et al., 2003). After an acute bout of intense plyometric exercise, the serum CK levels reached peak values from 48 through 72 hours of recovery (Chatzinikolaou et al., 2010). Peak serum CK values of approximately sevenfold above the baseline were found $48 \mathrm{~h}$ after a soccer game (Fatouros et al., 2010). There are marked differences between the sexes, with lower basal CK values in females than in males. Estrogen levels may be one important factor in maintaining membrane stability post-exercise (Tiidus, 2000). Creatine kinase serum levels can also be influenced by muscle mass and ethnicity (Eliakim et al., 1995).

While these studies make important contributions to the understanding of acute responses, they do not provide enough information for longitudinal, seasonal application in actively competing athletes. An important point to be considered is that serum CK activity can arise in the absence of histological lesions as a consequence of changes in the muscle membrane permeability (Manfredi et al., 1991). Thus, monitoring the changes in serum CK may represent an indirect route for monitoring workload effects and a way to prevent sub-clinical damage due to muscle overload. However, to be a useful tool for individual adjustments in the stimulus/recovery ratio during a competitive season, it is necessary to compare individual blood values with population-based reference intervals. With this knowledge, it is possible to individualize training program interventions to adjust overloads or medical/nutritional programs only when necessary. Prevention thus leads to economy for all.

One difficulty in assessing the effects of training through blood biomarkers is the lack of appropriate reference intervals obtained from a reference population practicing regular and systematized physical activity or sports modality. To solve this problem, we have recently determined the reference interval for the plasma CK activity of blood samples obtained from 128 professional soccer players at different times during the Brazilian Championship (Lazarim et al., 2009). The upper limits of the $97.5^{\text {th }}$ and $90^{\text {th }}$ percentiles for the CK activity were determined according to the International Federation of Clinical Chemistry (IFCC) rules and were $1.338 \mathrm{U} / \mathrm{L}(\mathrm{CI}=1191-1639 \mathrm{U} / \mathrm{L})$ and $975 \mathrm{U} / \mathrm{L}(\mathrm{CI}=810-1090 \mathrm{U} / \mathrm{L})$, respectively. These percentile values were markedly higher than the values previously reported in the literature (<207 U/L) (Rustad et al., 2004). Taking the upper limit of any percentile as the decision limit, the individual plasma CK activity above the upper reference limit may indicate the transition from adaptive microtrauma to a sub-clinical muscular injury, increasing the potential for histological damage.

In this study, we suggest the $90^{\text {th }}$ percentile $(975 \mathrm{U} / \mathrm{L})$ as the upper plasma CK limit for the early detection of muscle overload in competing soccer players (Lazarim et al., 2009). We hypothesized that the same muscle membrane alterations that may increase plasma CK activity also affect the release of growth factors by muscle cells (McNeil \& Khakee, 1992), explaining why changes in the plasma CK activity could also reflect muscular adaptation 
when the values are lower than the upper limit values. To test this hypothesis, we evaluated a soccer team monthly throughout the Championship. During the five moments of analyses, we detected only six players with plasma CK values that were higher than $975 \mathrm{U} / \mathrm{L}$. These players were asked to decrease their training for 1 week, after which they presented lower CK values. Only one player with a CK value higher than the decision limit (1800 U/L one day before a game) played on the field, and he was unfortunately injured during the game. The CK activity in all of the other players showed a significant decrease over the course of the Championship, and the values became more homogeneous toward the end.

Later, we showed that the $97.5^{\text {th }}$ percentile for a young population with improved performance after four months of systematic endurance training was similar $(<1309 \mathrm{U} / \mathrm{L}, \mathrm{CI}=$ $882-1464 \mathrm{U} / \mathrm{L}$ ) to that found in soccer players (Nunes \& Macedo, 2008). To us, this finding justified the use of blood samples from this physically active population to establish reference population intervals for analytes that respond to exercise stimulus, such as plasma glutamine and glutamate concentrations, which are discussed in another chapter of this book.

\subsubsection{Inflammatory response}

The response to AMT is a subsequent inflammation post-exercise, triggering tissue repair and remodeling. The activation of the inflammatory process is both local and systemic and is mediated by different cells and secreted compounds with pro- and anti-inflammatory activities. The objective is to reestablish organ homeostasis after a single bout of exercise or after several exercise sessions. The acute-phase response involves the combined actions of activated leukocytes, cytokines, acute-phase proteins, hormones, and other signaling molecules that control the response to an exercise session and guide the adaptations resulting from training (Gruys et al., 2005).

The leukocytes are the first cells of the immune system to respond to tissue damage (Smith, 2000), and the neutrophils are the first subpopulation to migrate to the damaged site (Tidball, 2005). Neutrophils are produced in the bone marrow and represent 50 to $60 \%$ of the total leukocytes in circulation (Toumi \& Best, 2003; Tidball, 2005b). Cortisol stimulates their release (Pyne, 1994), and their main function is the removal, by phagocytosis, of undesirable elements that are related to injury. To accomplish this removal, they release proteases to degrade proteins and produce superoxide anions $\left[\mathrm{O}_{2}{ }^{\bullet-}\right]$ and subsequently other reactive oxygen species (ROS; hydrogen peroxide $\left[\mathrm{H}_{2} \mathrm{O}_{2}\right]$ and hydroxyl radical [OH.]) through a respiratory burst that is catalyzed by NADPH oxidase and myeloperoxidase (Pyne, 1994; Tidball, 2005b). This action is the starting point for the subsequent response of repair and tissue growth.

The monocytes are the second subpopulation of leukocytes that migrate to the damaged tissue. In the cells, they undergo differentiation and become macrophages (Tidball, 2005b). Recently, it was proposed that the macrophages that invade the lesion site earlier (between 24-48 h) have different functions than do those that appear later (between 48-96 h). The main function of the first group is the removal of damaged tissue, whereas the later group has a more active function in muscular repair and secrete remodeling molecules, such as insulinlike receptor, cytokines and TGF- $\mathrm{a}$, that act in the recruitment and activation of fibroblasts and collagen secretion, contributing to tissue remodeling (Butterfield et al., 2006). Moreover, macrophages signal the activation, proliferation and differentiation of stem satellite cells, an important pathway for tissue remodeling (Pedersen et al., 1998).

The lymphocytes present a biphasic response to training. There is an increase during and immediately after the effort, especially of the Natural Killer (NK) cells, followed by a decrease 
that can last for hours (mainly of T and NK cells). The latter effect can lead to a transitory immunosuppressive state that is related to a higher susceptibility for upper respiratory tract infections as an acute effect of exhausting, prolonged exercise (Glesson, 2007; Pedersen et al., 1998). This phenomenon is known as an open window, and it can lead to increased susceptibility for infections post-exercise (Rowbottom \& Green, 2000; Glesson, 2007).

The literature related to exercise indicates distinct inflammatory responses to both acute and chronic exercise (Catanho da Silva \& Macedo, 2011). In general, acute exercise induces a proinflammatory response that is characterized by transient leukocytosis (neutrophilia, monocytosis, and lymphocytosis), followed by a partial cellular immunosuppressive state. After a single bout of physical activity, there is an increase in the number of circulating leukocytes that is related to the intensity and duration of the exercise (Gleeson, 2007). Other substances related to leukocyte function, including inflammatory cytokines and inflammatory acute phase proteins are also increased. These values are generally normalized to basal concentrations within 3-24 hours (Gleeson, 2006). An increase in the serum concentrations of creatine kinase, C-reactive protein and cell adhesion molecules is also observed, in addition to an increase in the secretion of cortisol and cytokines (Pedersen \& Hoffman-Goetz, 2000; Steensberg et al., 2000).

In contrast, chronic exercise (training) seems to result in a local and systemic imbalance in the anti-inflammatory status as compared to the pro-inflammatory status. This imbalance promotes tissue adaptation and protects the organism against the development of chronic inflammatory diseases and against the deleterious effects of overtraining, a condition in which a systemic and chronic proinflammatory and pro-oxidant state seems to prevail (Petersen \& Pedersen, 2005; Catanho da Silva \& Macedo, 2011). Some studies have shown an attenuation in the production and secretion of acute phase proteins, especially PCR (Kasapis \& Thompson, 2005), greater production and secretion of anti-inflammatory proteins (IL-6) (Petersen \& Pedersen, 2005) and improved antioxidant status (Petersen \& Pedersen, 2005; Ji, 1999). A possible transient alteration in the production of IL-1 $\beta$ and TNF is dependent upon the exercise type, intensity and duration (Petersen \& Pedersen, 2005). Adipose tissue also has been investigated in chronic protocols and has shown the same anti-inflammatory pattern (Lira et al., 2009).

In general, there is little evidence available to suggest clinical differences between the immune functions of sedentary and exercised subjects. Some studies have reported a lower frequency of upper respiratory tract infections in persons who are moderately active as compared to those with a sedentary lifestyle (Gleeson, 2007). Cross-sectional studies that have compared leukocyte numbers in sedentary control groups with athletes more than 24 hours after their last training session have generally found few differences (Gleeson, 2006).

We established reference intervals for hemogram in a large population $(n=357)$ after four months of systematized endurance training. We followed the criteria established by the International Federation of Clinical Chemistry (IFCC). The outliers were detected and removed before the estimation of the reference interval by Horn's algorithm (Horn et al., 2001). The RefVal program (Solberg, 2004), including practical approaches and formulas recommended by the IFCC, was used to calculate the non-parametric $2.5^{\text {th }}$ and $97.5^{\text {th }}$ percentiles, together with their $90 \%$ confidence intervals $(\mathrm{CI})$, using a Bootstrap methodology. Table 1 shows the lower limit $\left(2.5^{\text {th }}\right.$ percentile) and upper limit $\left(97.5^{\text {th }}\right.$ percentile) of the reference intervals and their respective $90 \%$ confidence intervals for hematological parameters. 


\begin{tabular}{ccccccc}
\hline \multirow{2}{*}{ Analysis } & $\begin{array}{c}\text { Reference } \\
\text { Interval }\end{array}$ & \multicolumn{2}{c}{ 90\% Confidence Interval } & $\begin{array}{c}\text { Subjects } \\
(\mathbf{n})\end{array}$ & $\begin{array}{c}\text { Outliers } \\
(\mathbf{n})\end{array}$ & $\begin{array}{c}\text { Total } \\
\text { Subjects }\end{array}$ \\
\cline { 3 - 6 } & $2.5^{\text {th }}-97.5^{\text {th }}$ & $2.5^{\text {th }}$ & $97.5^{\text {th }}$ & & & \\
\hline RBC $\left(10^{12} / \mathrm{L}\right)$ & $4.4-5.6$ & $4.3-4.5$ & $5.6-5.7$ & 357 & 5 & 352 \\
Ht (\%) & $39.5-48.0$ & $39.0-40.2$ & $47.7-48.8$ & 357 & 3 & 354 \\
Hgb (g/dL) & $13.0-16.1$ & $12.8-13.2$ & $15.9-16.3$ & 357 & 2 & 352 \\
MCV (fL) & $80.9-94.9$ & $80.0-82.3$ & $94.3-95.4$ & 357 & 6 & 351 \\
MCH (pg) & $26.1-31.6$ & $25.7-26.5$ & $31.4-31.7$ & 357 & 9 & 348 \\
RDW (\%) & $12.1-14.3$ & $12.0-12.1$ & $14.1-14.4$ & 357 & 16 & 341 \\
WBC (109/L) & $4.5-10.1$ & $4.2-4.7$ & $9.7-10.4$ & 357 & 12 & 345 \\
Lym (109/L) & $1.2-3.3$ & $1.2-1.3$ & $3.15-3.4$ & 357 & 4 & 353 \\
Neut (109/L) & $1.8-6.7$ & $1.7-2.0$ & $6.5-7.0$ & 353 & 10 & 343 \\
PLT (109/L) & $140-337$ & $135-147$ & $307-350$ & 357 & 4 & 353 \\
\hline
\end{tabular}

Table 1. Reference intervals, confidence intervals and outliers obtained from a hemogram of physically active individuals.

We found slightly higher values for counts of leukocytes $\left(4.5 \times 10^{9}-10.1 \times 10^{9} / \mathrm{L}\right)$ and neutrophils $\left(1.8 \times 10^{9}-6.7 \times 10^{9} \mathrm{cel} / \mathrm{L}\right)$ in our physically active population as compared to sedentary individuals $\left(3.5 \times 10^{9}-9.8 \times 10^{9} / \mathrm{L}\right.$ and $1.4 \times 10^{9}-6.6 \times 10^{9} / \mathrm{L}$, respectively) (Kjeldsberg, 1992). Our reference ranges are narrower than the traditional reference intervals for leukocyte counts, mainly due to the homogeneity of the reference population. The $2.5^{\text {th }}$ and $97.5^{\text {th }}$ percentile of the lymphocyte and platelet counts found were similar to those of healthy, nonexercised population values $\left(\mathrm{Lym}=1.2-3.5 \times 10^{9} / \mathrm{L}\right)$ and $\left(\mathrm{PLT}=145-348 \times 10^{9} / \mathrm{L}\right)$ (Kjeldsberg, 1992; Nordin et al., 2004), indicating no training effects on these parameters.

The erythrogram is a part of the hemogram that evaluates the red blood cell (RBC) number, volume and hemoglobin content. Erythrograms can be useful to diagnose sports anemia, which can impair the athlete's performance (Sottas et al., 2010, Schumacher et al., 2002). Exercise-induced hemolysis has been reported for more than 50 years (Gilligan et al., 1943). This phenomenon is associated with the destruction of red blood cells (RBC), with higher $\mathrm{RBC}$ turnovers in runners as compared to non-trained subjects, although it is commonly observed in other modalities (e.g., swimming, weight lifting, rowing) (Telford et al., 2003). A persistent decrease in the hemoglobin concentration, decreases in indices such as the mean corpuscular volume and the hemoglobin corpuscular volume and an increase in red distribution width (RDW) can also indicate iron deficiency (Zoller \& Vogel, 2004). Three subjects presented higher RBC values and lower MCV values, characteristics of thalassemia, while four subjects were detected to have microcytosis (MCV $<80.0 \mathrm{fL}$ and RDW $>15 \%)$ and hypochromia $(\mathrm{HCM}=26.0 \mathrm{pg})$, suggestive of an iron deficiency: these subjects were classified as outliers and were excluded from the calculations of the reference intervals.

The data presented in Table 1 show a more narrow reference interval for RBC, hematocrit and hemoglobin in our population as compared to a sedentary subject's values (RBC $=4.4-$ $5.9 \times 10^{12} / \mathrm{L}$; hematocrit $=40-50 \%$ and hemoglobin $\left.13-18 \mathrm{~g} / \mathrm{dL}\right)($ Kjeldsberg, 1992). The mean erythrocyte lifespan in athletes and physically active subjects may be shorter than that in non-exercised subjects, mainly due to the exercise-induced hemolysis that is inherent to 
endurance training (Weight et al., 1991). This lifespan may lead to the narrow values observed in the red blood cell parameters in our study. The accelerated turnover and increased rate of $\mathrm{RBC}$ production in endurance trained subjects can lead to a steady state of a population of younger RBCs, which are more efficient at oxygen transportation due partly to higher 2,3-diphosphoglycerate concentrations (Smith, 1995).

\subsubsection{Nitrogen compounds}

A prolonged, uncontrolled local neutrophil action can damage other cells near the inflammatory site due to increases in ROS production, which compromises the integrity of the muscle cells, contributing to systemic inflammation (Tidball, 2005b). A series of enzymatic and non-enzymatic antioxidants (Ji, 1999) limit the biological activity of ROS. Uric acid is one of the most important non-enzymatic antioxidants in plasma and tissues (Lippi et al., 2008). In addition, the plasma antioxidant system is also composed of other molecules and enzymes, such as ascorbic acid, proteins, vitamin E, bilirubin and peroxidases (Finaud et al., 2006).

Athletes and physically active subjects displayed an enhanced antioxidant capacity (Carlsohn et al., 2008) with increased serum concentrations of uric acid (Finaud et al., 2006). It was suggested that urate quantification could be useful for monitoring athletes in training (Youssef et al., 2008). We have found (Nunes et al., 2010) a slightly higher serum uric acid reference interval in athletes $(0.24-0.49 \mathrm{mmol} / \mathrm{L})$ than in sedentary subjects $(0.23-0.47$ $\mathrm{mmol} / \mathrm{L}$ ) (Rustad et al., 2004). This difference can be explained by the intensity of the subject's training (Finaud et al., 2006).

Biomarkers, such as serum creatinine and urea, are also used to monitor the effects of training. The urea is an end product of the degradation of nitrogenous compounds from proteins; it is synthesized in the liver and is excreted by kidneys. The main factors influencing the higher urea serum levels found during the training period may be the increased consumption and protein turnover, the reduced water intake and the incomplete replenishment of glycogen after exercise (Hartmann \& Mester, 2000). The serum concentrations of urea have been used as a marker of protein catabolism and were found to stimulate gluconeogenesis during higher training loads. It was proposed that monitoring the serum urea concentrations and the CK activity may indicate an acute impairment in exercise tolerance (Urhausen \& Kindermann, 2002; Lehmann et al., 1998). The serum urea level seems to respond to exercise training, and the upper limit of the reference interval observed by Nunes \& Macedo (2008) $(3.0-8.51 \mathrm{mmol} / \mathrm{L})$ in physically active subjects at a well-trained stage is higher compared than that of a non-exercised healthy population (3.20 $8.20 \mathrm{mmol} / \mathrm{L}$ ) (Rustad et al., 2004).

Serum creatinine concentrations have long been the most widely used and commonly accepted biomarker of renal function in clinical medicine (Perrone et al., 1992). Their concentrations can be modified by age, sex, ethnicity, muscle mass and exercise (Banfi et al., 2009). The serum creatinine concentrations found in professional athletes can vary according to their modality, the training load, their aerobic/anaerobic metabolism, the frequency of their competitions, the lengths of their competition and the annual training period (Banfi et al., 2009). The creatinine reference intervals commonly used for sedentary people are $62.0-$ $115.0 \mu \mathrm{mol} / \mathrm{L}$. In physically active individuals, we observed higher values (77.8 - 132.6 $\mu \mathrm{mol} / \mathrm{L}$ ) (Nunes \& Macedo, 2008), which are typically influenced by the higher muscle mass that is found in exercised populations, as observed by Banfi \& Del Fabro (2006).

Our data have shown that the reference intervals were significantly higher in trained subjects than in a non-exercised population, suggesting a training effect on blood analytes, 
such as the hemogram, which were slightly different from those values reported in the literature for a healthy, non-exercised population (Kjeldsberg, 1992; Nordin et al., 2004). In the biochemical parameters, the main differences found were as follows: urea $(3.0-8.51 \mathrm{mmol} / \mathrm{L})$, creatinine $(77.8$ - $132.6 \mu \mathrm{mol} / \mathrm{L})$, uric acid $(0.24-0.49 \mathrm{mmol} / \mathrm{L})$, creatine kinase $(<1309 \mathrm{U} / \mathrm{L})$, aspartate aminotransferase ( $<62 \mathrm{U} / \mathrm{L})$ and C-reactive protein $(<19.8 \mathrm{mg} / \mathrm{L})$, all of which had higher reference intervals in trained subjects as compared to a non-exercised population (Nunes \& Macedo, 2008). Now that the lower and upper reference values for the blood analytes of an exercised population are known, it will be possible to use these biomarkers to differentiate between the adaptation and maladaptation states that are induced by training.

\subsection{Biological variation and reference change values}

A comparison of individual blood parameter values with the reference intervals obtained from a defined, physically active population has certain limitations, one of which is that the laboratory test results may be influenced by natural fluctuations that are particular to a given analyte: this phenomenon is called biological variation (Fraser, 2004). This biological variation should be assessed in longitudinal studies with serial blood analyses of the same subjects. For example, a determined analyte concentration can change over time within an individual, reflecting the random temporal variation of an analyte in homeostasis that can occur during steady state conditions (Ricos et al., 2004).

The point of biological homeostasis (estimated by the arithmetic mean value, $\mu$ ) is different for each person, and it is assumed to be constant for a certain period (e.g., months, years). The biological within-subject variation is described by the standard deviation ( $\sigma)$, which is obtained from measurements around the mean value (Petersen, 2005). To facilitate the comparison between individuals and analytes, the coefficient of intra-individual variation $\left(\mathrm{CV}_{\mathrm{I}} \%\right)$ is calculated from the following equation:

$$
\mathrm{CV}_{\mathrm{I}}=\sigma / \mu \times 100
$$

The Table 2 shows an example of the biological variation in the serum CK activity from samples that were collected monthly during the training/competition season of six soccer players.

\begin{tabular}{ccccccccc}
\hline Athletes & $\begin{array}{c}\mathbf{1}^{\text {st }} \\
\text { result }\end{array}$ & $\begin{array}{c}\mathbf{2}^{\text {nd }} \\
\text { result }\end{array}$ & $\begin{array}{c}\mathbf{3}^{\text {rd }} \\
\text { result }\end{array}$ & $\begin{array}{c}\mathbf{4}^{\text {th }} \\
\text { result }\end{array}$ & $\begin{array}{c}\mathbf{5}^{\text {th }} \\
\text { result }\end{array}$ & $\begin{array}{c}\text { Individual } \\
\text { mean }(\boldsymbol{\mu})\end{array}$ & $\begin{array}{c}\text { Standard } \\
\text { deviation } \\
(\mathbf{\sigma})\end{array}$ & $\begin{array}{c}\mathbf{C V}_{\mathbf{I}} \\
\mathbf{( \% )}\end{array}$ \\
\hline 1 & 1232 & 911 & 1239 & 1232 & 1380 & 1232 & 173 & 14 \\
2 & 424 & 455 & 327 & 347 & 324 & 347 & 60 & 17 \\
3 & 218 & 218 & 147 & 247 & 189 & 218 & 38 & 17 \\
4 & 1214 & 1055 & 667 & 557 & 560 & 667 & 304 & 46 \\
5 & 205 & 111 & 230 & 116 & 137 & 137 & 54 & 40 \\
6 & 427 & 173 & 200 & 181 & 273 & 200 & 67 & 33 \\
\hline
\end{tabular}

Table 2. Coefficient of intra-individual variation $\left(\mathrm{CV}_{\mathrm{I}}\right)$ related to serum $\mathrm{CK}$ activity $(\mathrm{U} / \mathrm{L})$ of six male soccer players.

These data show that each athlete has a different point of homeostasis for CK activity (represented here as the individual mean), and this is also true for any other analyte. These individual values span different parts of the reference interval for CK activity (Lazarim et al., 2009). 
Another component of biological variation is the coefficient of variation between subjects $\left(\mathrm{CV}_{\mathrm{G}}\right)$, which is obtained via the mean and standard deviation between different subjects. For example, if ten soccer players exhibited mean serum CK values of $390 \mathrm{U} / \mathrm{L}$ with a standard deviation of $266 \mathrm{U} / \mathrm{L}$ from blood samples collected after one month of training, the calculated $\mathrm{CV}_{\mathrm{G}}$ for these soccer players is $68 \%$.

Both $\mathrm{CV}_{\mathrm{I}}$ and $\mathrm{CV}_{\mathrm{G}}$ are influenced by age, sex, weight, diet, circadian rhythm, pathologies and physical activity (Ricós et al. 2004), and it is possible to estimate them using data banks that are available in the literature for many analytes in healthy, non-exercised subjects (Ricos et al., 1999). In addition to the biological variation, pre-analytical and analytical variation can also influence the laboratory test results. The pre-analytical variation can be minimized through the adoption of standardized instructions for the patients before sample collection, handling and transportation (Banfi \& Dolci, 2003). All analytical measurement techniques (manual or automatic) have some intrinsic sources of variability. This variability cannot be completely eliminated, but it can be minimized by quality laboratory practices and the choice of sound equipment, reagents and methodologies (Fraser, 2001). We can usually identify two types of analytical variation: random (precision) and systematic (bias).

The precision of one methodology or piece of equipment is measured by replicate analysis of the same sample (a control sample). The precision will be influenced by the analytical conditions. If we use the same equipment, technician, reagent lots and calibration, we will generate smaller variations than if we take replicate results over a long period, varying these components (Fraser, 2001). The precision has a Gaussian distribution, and we can calculate the coefficient of analytical variation $\left(\mathrm{CV}_{\mathrm{A}} \%\right)$ from the mean and standard deviation of control sample replicates. The International Organization for Standardization (ISO) defines bias as the difference between the expectation of the measurement results and the true value of the measured quantity. In practice, bias is the difference between the results that we obtain and some estimate of the true value (Fraser, 2001).

The analytical variation can be monitored by an internal quality control (IQC) program. The protocol of IQC should include control samples that simulate the matrix of the sample analysis (Westgard, 2004). The statistical analysis of the quality control can be performed through the Levey-Jennings flow chart for each analyte and the correct applications of the Westgard control rules (Westgard, 2004). In addition, the level of performance must be established. The most widely applied term is quality specifications. Other terms include quality goals, quality standards, desirable standards, analytical goals, and analytical performance goals (Fraser, 2001). Considering that all analytes suffer from the influence of biological variation (intra- and inter-individual), one useful quality specification is based on biology (Fraser \& Petersen, 1999). In this model, the quality specification has 3 levels for judging imprecision: desirable performance is defined as $\mathrm{CV}_{\mathrm{A}}<0.5 \times \mathrm{CV}_{\mathrm{I}}$; optimum performance is defined as $\mathrm{CV}_{\mathrm{A}}<0.25 \times \mathrm{CV}_{\mathrm{I}}$ and the minimum performance is defined as $\mathrm{CV}_{\mathrm{A}}<0.75 \times \mathrm{CV}_{\mathrm{I}}$ (Fraser \& Petersen, 1999).

The analysis of consecutive samples by comparison with values from a reference population is useful mainly when $\mathrm{CV}_{\mathrm{I}}>\mathrm{CV}_{\mathrm{G}}$ (Fraser 2004). However, the majority of analytes that are quantified in the clinical laboratory have $\mathrm{CV}_{\mathrm{I}}<\mathrm{CV}_{\mathrm{G}}$. In this case, the comparison of an individual result with a population-based reference interval might not be useful in monitoring slight effects because some individuals may show significant changes in serial testing that are within the normal limits of a reference population (Petersen et al., 1999).

A proposed alternative tool to verify a significant and biologically relevant difference between two consecutive analyses is the reference change value (RCV) or critical difference calculation 
(Harris \& Yasaka, 1983; Ricos et al., 2004). The RCV defines the percentage of change that must be exceeded given the inherent biological and analytical variation in the test. This tool can increase the sensitivity of serial analyses due to the exclusion of false positive results.

\subsection{Calculating reference change values}

The total variation associated with a laboratory test result is the sum of the component variations (pre-analytical, analytical and intra-individual biological variation). The preanalytical variation can be minimized if we standardize the conditions of patient preparation and the procedures for collecting and handling the samples. Therefore, we must consider only the biological and analytical variation when calculating the total variation $\left(\mathrm{CV}_{\mathrm{T}}\right)$ according equation 2 (Fraser \& Harris, 1989).

$$
\mathrm{CV}_{\mathrm{T}}=\left(\mathrm{CV}_{\mathrm{A}}^{2}+\mathrm{CV}_{\mathrm{I}}^{2}\right)^{1 / 2}
$$

The coefficient of analytical variation $\left(\mathrm{CV}_{\mathrm{A}}\right)$ can easily be obtained from the mean and standard deviation of the control sample analytes, and the $\mathrm{CV}_{\mathrm{I}}$ is available in the data bank for most of the analytes from healthy subjects (Ricos et al., 1999) or physically active subjects (Nunes et al., 2010).

The term RCV was introduced by Harris \& Yasaka (1983) and can be calculated by the following equation (3):

$$
\mathrm{RCV}=2^{1 / 2} \times \mathrm{Zp} \times\left(\mathrm{CV}_{\mathrm{A}}^{2}+\mathrm{CV}_{\mathrm{I}}^{2}\right)^{1 / 2}
$$

Where $2^{1 / 2}$ denotes the probability of bidirectional change, and $\mathrm{Zp}$ denotes the standard deviation corresponding to the level of statistical significance for the bidirectional change $(1.96=95 \%$ and $2.58=99 \%)$ (Harris \& Yasaka; 1983; Fraser \& Harris, 1989).

Recently, we have established the respective $\mathrm{RCV}_{95 \%}$ for hemograms and for certain biochemical parameters from individuals who had undergone 4 months of regular and planned physical activity (Nunes el al., 2010). We showed that the RCV values for leukocytes and for all biochemical analytes were elevated as compared to the literature values of sedentary subjects, clearly indicating a training effect on these blood analytes. However, the RCV values for the red blood cell count were slightly lower in physically active than in sedentary individuals (Nunes el al., 2010).

Soccer is the most widely played sport worldwide, and it also has many different cultural, social and economic aspects. The elite soccer player must have good, but not exceptional, all-around physical strength and must be able to effectively respond to the diverse demands of the game. Several studies have determined the pattern of activities performed and the individual distance covered during a game: these values have been used as an indication of the total work performed. It is well accepted that outfield players cover 8-12 km during a game that involves many different activities, with a rapid change in the type or level of activity each 4-6 seconds (Reilly, 1997; Bangsboo, 1994). While the majority of the exercise associated with competitive soccer is at sub-maximal intensities, the intermittent efforts with higher energy demands should not be slighted during a match, and often their successful execution determines the results of a game (Bangsbo et al., 2006).

The trade of elite soccer players produces large sums of money and affects the emotional state of soccer fans all around the world. Great savings can therefore be obtained by elite 
soccer players and their clubs with the physical protection of athletes. Our aim in this study was to verify the applicability of the reference interval described here and the previously determined RCVs (Nunes et al., 2010) for monitoring, through hematological and biochemical analyses, the effects of training/competition on soccer players during five months of the competitive season.

\section{Material and methods}

\subsection{Subjects}

Fifty-six male soccer players (17-19 years old) participated in this study. The athletes were evaluated during four months that included both training (pre-season) and competitive periods (regional soccer championship for players under 20). The volunteers responded to a questionnaire about their use of medications and complaints of pain and injuries caused by training or competition. Those who were using medications or who were injured were not included in the study. Volunteer subjects were duly informed about the research and signed an informed consent form. This research was approved by the Human Research Ethics Committee of the University (CAAE: 0200.0.146.000-08).

\subsection{Collection of blood samples}

The subjects were longitudinally evaluated through five blood samples that were collected monthly [C1 = pre-competitive period of training; $\mathrm{C} 2=$ after 1 month (training); $\mathrm{C} 3=$ after 2 months (training and beginning of competitions); $\mathrm{C} 4=$ after 3 months (training and competitions); and C5 = after 4 months (mainly competitions)]. The blood samples were collected under standardized conditions: $2.0 \mathrm{~mL}$ of total venous blood was collected in vacuum tubes containing EDTA/K3 to determine the hematological parameters, and $8.0 \mathrm{~mL}$ of venous blood was collected in tubes with a Vacuette ${ }^{\circledR}$ (Greiner Bio-one) gel separator to obtain serum for the biochemical measurements. The blood samples were collected in the morning after 12 hours of fasting, in a seated position, and they were transported at $4^{\circ} \mathrm{C}$ to the laboratory within 30 minutes, centrifuged under refrigeration at 1,800 x g for 10 minutes, were immediately separated, and were protected from light. All blood samples were collected after two days of rest to avoid the effects of hemodynamic variations and the acute hemodilution that is induced by exercise (Sawka et al., 2000).

\subsection{Hematological and biochemical analysis}

The hematological parameters were measured with a KX-21N Sysmex® analyzer, and the biochemical analyses (CK activity, uric acid, urea and creatinine concentration) were run in an Autolab analyzer (Boehringer) using commercial kits (Wiener Lab, Rosario, Argentina). All analyses were run in parallel with commercial serum and blood controls. To minimize analytical variations, all samples were tested by the same technician without changing reagent lots, standards, or control materials.

\subsection{Statistical analysis}

The percent differences between the serial results were calculated for each subject using Microsoft Excel® and were compared with $\mathrm{RCV}_{95 \%}$ to detect significant changes. As the activity of CK had a value distribution that was slightly skewed to the right, we opted to transform the data using natural logarithms (Wu et al., 2009). The Matlab 7.0 software was used to generate graphs. 


\section{Results}

Figure 1 presents, as an example, the CK values analyzed in comparison to both the upper reference limit and the RCV established from a physically active population (Nunes \& Macedo, 2008; Nunes et al., 2010). Thus, Figure 1A presents the CK values (mean, minimum and maximum) for each soccer player at five time points in comparison with the reference upper limit (97.5th percentile $-<1.309 \mathrm{U} / \mathrm{L}$ ), and Figure 1B presents the percentage change between successive pairs of serial results of the five time points in comparison to the RCV $(119.8 \%)$.

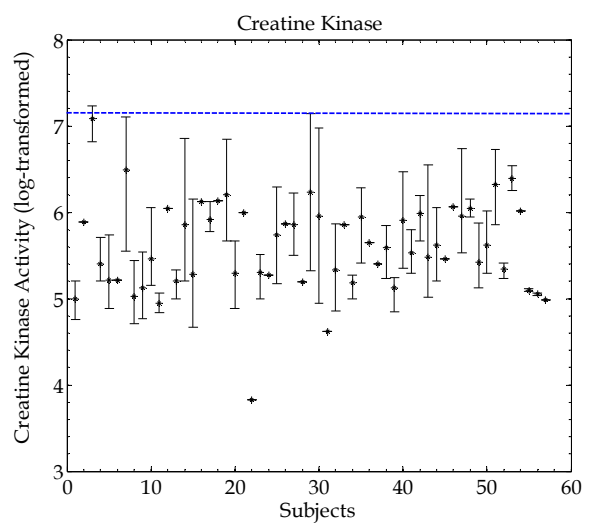

A.

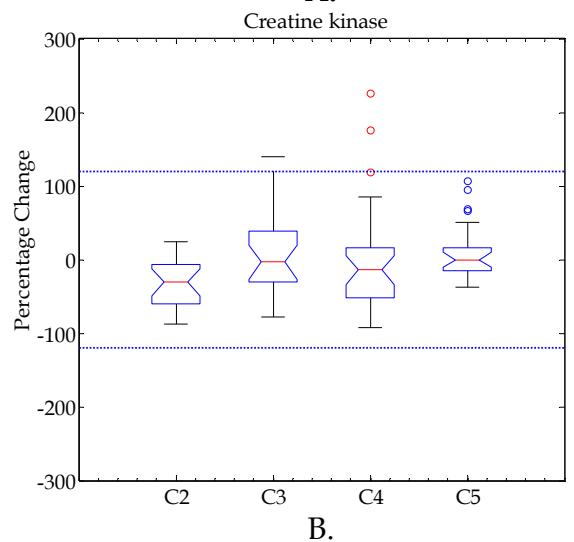

Fig. 1. (A.) CK values (mean, minimum and maximum) for each soccer player at five time points. The dotted horizontal lines indicate the reference interval $(97.5 \%$ upper limit $=1309$ $\mathrm{U} / \mathrm{L}$ ) from a physically active population. (B.) CK percentage change between successive pairs of serial results of the soccer players during the training/competition season. The dotted horizontal lines indicate the RCV 95\% for CK $=119.3 \%$.

We can observe that the five consecutive results for all individuals were within the reference upper values (Figure 1A). However, the comparison of the serial analytes to the RCV showed a significant increase of $119.8 \%$ in three players (Figure 1B), even though the serial results were within the upper reference limit. 
It is important to point out that the behavior observed in Figure $1 \mathrm{~A}$ and $1 \mathrm{~B}$ was the same for all other analytes monitored. Thus, we will show only those athletes who presented at any time point a significant change, based on the RCV values, as compared to the previous analysis. The results are presented in Table 3.

\begin{tabular}{|c|c|c|c|c|}
\hline Analyte & Time point & Players & $\begin{array}{c}\text { Measured values } \\
\text { current - previous }(\Delta)\end{array}$ & $\begin{array}{l}\text { Percentage } \\
\text { change }(\%)\end{array}$ \\
\hline \multirow{3}{*}{$\begin{array}{c}\mathrm{CK}(\mathrm{U} / \mathrm{L}) \\
\mathrm{RCV}_{95 \%}=119.3 \% \\
\mathrm{RI}=1309 \mathrm{U} / \mathrm{L}\end{array}$} & $\mathrm{C} 3$ & 35 & $535-223(312)$ & +139.9 \\
\hline & \multirow{2}{*}{$\mathrm{C} 4$} & 14 & $951-345(606)$ & +175.7 \\
\hline & & 19 & $942-289(653)$ & +226.0 \\
\hline \multirow{13}{*}{$\begin{array}{c}\text { Urea }(\mathrm{mmol} / \mathrm{L}) \\
\operatorname{RCV}_{95 \%}=42.5 \% \\
\text { RI }=3-8.5 \mathrm{mmol} / \mathrm{L}\end{array}$} & \multirow{8}{*}{$\mathrm{C} 2$} & 8 & $6.2-3.7(2.5)$ & +68.2 \\
\hline & & 14 & $4.7-3.2(1.5)$ & +47.4 \\
\hline & & 19 & $7.7-5.0(2.7)$ & +53.3 \\
\hline & & 23 & $4.4-2.7(1.7)$ & +62.5 \\
\hline & & 25 & $3.8-2.6(1.2)$ & +43.8 \\
\hline & & 27 & $5.3-3.5(1.8)$ & +52.4 \\
\hline & & 29 & $4.9-3.4(1.5)$ & +45 \\
\hline & & 32 & $6.4-3.7(2.7)$ & +72.7 \\
\hline & $\mathrm{C} 3$ & 9 & $4.2-4.34(1.3)$ & +47.1 \\
\hline & \multirow{4}{*}{$\mathrm{C} 4$} & 3 & $4.9-2.9(2)$ & +70.6 \\
\hline & & 32 & $3.3-6.3(-3)$ & -47.4 \\
\hline & & 38 & $5.8-4.0(1.8)$ & +45.8 \\
\hline & & 42 & $3.8-2.6(1.2)$ & +43.8 \\
\hline \multirow{5}{*}{$\begin{array}{c}\text { Creatinine }(\mu \mathrm{mol} / \mathrm{L}) \\
\mathrm{RCV}_{95 \%}=26.8 \% \\
\mathrm{RI}=77.8-132.6 \\
\mu \mathrm{mol} / \mathrm{L}\end{array}$} & \multirow{5}{*}{ C3 } & 4 & $113-87.6(25.4)$ & +29.3 \\
\hline & & 7 & $95.4-74.2(21.2)$ & +28.6 \\
\hline & & 15 & $93.7-70.7(23)$ & +32.5 \\
\hline & & 42 & $95.4-73.4(22)$ & +30.1 \\
\hline & & 44 & $121.0-88.0(33)$ & +37 \\
\hline
\end{tabular}

$\mathrm{RI}=$ reference interval for physically active subjects; $\mathrm{RCV}=$ reference change value for physically active subjects; $\Delta=$ absolute difference between 2 consecutive analyses.

Table 3. Soccer players and their biochemical analytes with significant change based on RCV values.

One player at C3 and two at C4 presented CK values above $119.3 \%$. The serum urea concentrations were significantly increased in eight subjects after the first month of training (C2). Five athletes showed creatinine values that were significantly increased at C3. Note that all of the altered analytes were inside of the reference intervals for the physically active population.

The Table 4 presents the results of the hematological parameters of those athletes that showed significant changes, based on the RCV values, as compared to the previous analysis. 


\begin{tabular}{|c|c|c|c|c|}
\hline Analyte & Time point & Players & $\begin{array}{c}\text { Measured values } \\
\text { current - previous }(\Delta)\end{array}$ & $\begin{array}{l}\text { Percentage } \\
\text { change }(\%)\end{array}$ \\
\hline \multirow{9}{*}{$\begin{array}{c}\operatorname{WBC}\left(10^{9} / \mathrm{L}\right) \\
\mathrm{RCV}_{95 \%}=43.9 \% \\
\mathrm{RI}=4.5-10.110^{9} / \mathrm{L}\end{array}$} & \multirow[t]{2}{*}{$\mathrm{C} 2$} & 1 & $7.8-4.5(3.3)$ & +73.3 \\
\hline & & 4 & $6.2-4.0(2.2)$ & +55 \\
\hline & \multirow{3}{*}{$\mathrm{C} 3$} & 14 & $9.6-6.5(3.1)$ & +47.7 \\
\hline & & 15 & $7.2-4.9(2.3)$ & +46.9 \\
\hline & & 44 & $9.3-5.3(4.0)$ & +75.5 \\
\hline & $\mathrm{C} 4$ & 19 & $10.1-5.4(4.7)$ & +105.6 \\
\hline & \multirow{3}{*}{ C5 } & 20 & $9.8-6.6(3.2)$ & +48.5 \\
\hline & & 47 & $8.1-4.8(3.3)$ & +68.8 \\
\hline & & 53 & $7.1-4.5(2.6)$ & +57.8 \\
\hline \multirow{11}{*}{$\begin{array}{c}\text { Neutrophils }\left(10^{9} / \mathrm{L}\right) \\
\mathrm{RCV}_{95 \%}=65.3 \% \\
\mathrm{RI}=1.8-6.710^{9} / \mathrm{L}\end{array}$} & \multirow{3}{*}{$\mathrm{C} 2$} & 1 & $5.1-2.3(2.8)$ & +119.5 \\
\hline & & 4 & $4.5-2.4(2.1)$ & +84.9 \\
\hline & & 23 & $4.0-2.4(1.6)$ & +69.7 \\
\hline & \multirow{3}{*}{$\mathrm{C} 3$} & 14 & $6.9-3.7(3.2)$ & +86.4 \\
\hline & & 15 & $4.8-2.5(2.3)$ & +92.9 \\
\hline & & 44 & $6.4-3.0(3.4)$ & +113.8 \\
\hline & \multirow{2}{*}{$\mathrm{C} 4$} & 19 & $8.6-3.0(5.6)$ & +182.7 \\
\hline & & 42 & $3.9-2.2(1.7)$ & +79.6 \\
\hline & \multirow{3}{*}{$\mathrm{C} 5$} & 20 & $7.9-3.7(4.2)$ & +112.2 \\
\hline & & 47 & $4.8-1.9(2.9)$ & +150.8 \\
\hline & & 53 & $4.9-2.4(2.5)$ & +104.6 \\
\hline \multirow{9}{*}{$\begin{array}{c}\text { Hemoglobin }(\mathrm{g} / \mathrm{dL}) \\
\mathrm{RCV}_{95 \%}=8 \% \\
\mathrm{RI}=13-16 \mathrm{~g} / \mathrm{dL}\end{array}$} & $\mathrm{C} 2$ & 23 & $13.2-14.4(-1.2)$ & -8.3 \\
\hline & \multirow{7}{*}{ C3 } & 7 & $15.2-14.0(1.2)$ & +8.6 \\
\hline & & 15 & $15.7-14.5(1.2)$ & +8.3 \\
\hline & & 17 & $15.3-13.3(2.0)$ & +15 \\
\hline & & 23 & $14.8-13.2(1.6)$ & +12.1 \\
\hline & & 39 & $16.5-14.7(1.8)$ & +12.2 \\
\hline & & 42 & $13.8-12.5(1.3)$ & +10.4 \\
\hline & & 43 & $15.6-13.7(1.9)$ & +13.9 \\
\hline & $\mathrm{C} 4$ & 23 & $13.6-14.8(-1.2)$ & -8.1 \\
\hline \multirow{8}{*}{$\begin{array}{c}\mathrm{RBC}\left(10^{12} / \mathrm{L}\right) \\
\mathrm{RCV}_{95 \%}=8.3 \% \\
\mathrm{RI}=4.4-5.610^{12} / \mathrm{L}\end{array}$} & \multirow{7}{*}{$\mathrm{C} 3$} & 7 & $5.3-4.8(0.5)$ & +10 \\
\hline & & 17 & $5-4.3(0.7)$ & +15.9 \\
\hline & & 20 & $4.3-4.8(-0.5)$ & -9.8 \\
\hline & & 23 & $5.1-4.6(-0.5)$ & +10.3 \\
\hline & & 39 & $5.4-4.9(0.5)$ & +10.4 \\
\hline & & 42 & $5.1-4.6(0.5)$ & +10.4 \\
\hline & & 43 & $5.3-4.7(0.6)$ & +14.1 \\
\hline & $\mathrm{C} 4$ & 20 & $5.0-4.3(0.7)$ & +10.3 \\
\hline
\end{tabular}

$\mathrm{RI}=$ reference interval for physically active subjects; $\mathrm{RCV}=$ reference change value; $\Delta=$ absolute difference between 2 consecutive analyses.

Table 4 . Soccer players and their hematological parameters with significant changes based on $\mathrm{RCV}$ values. 
Nine athletes were found to have elevated leukocyte counts, mainly neutrophils, at one or more time points. We found seven athletes with hemoglobin values that were significantly increased at C3. It is important to point out that all variations in these hematological parameters were within the reference intervals shown here (Table 1). The exception for this rule was the serum uric acid concentrations, as shown in Figure 2.

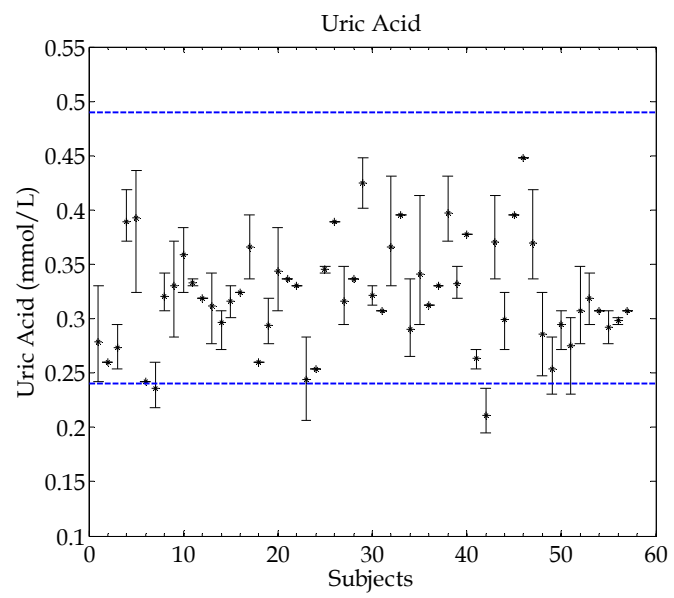

A.

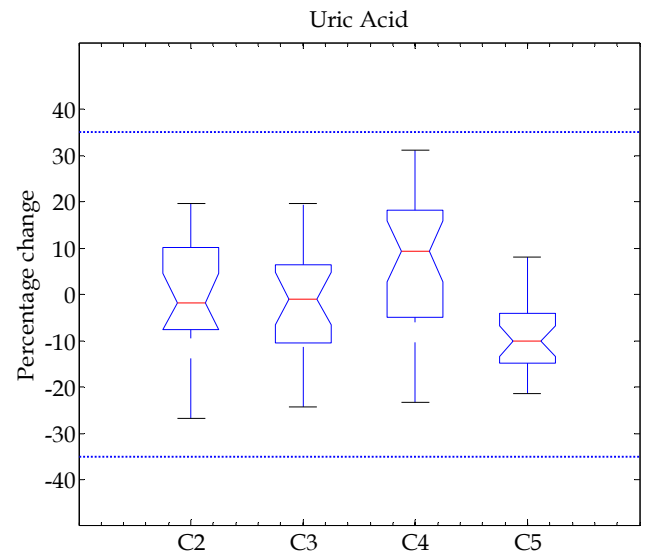

B.

Fig. 2. (A.) Uric acid concentration (mean, minimum and maximum) for each soccer player at five time points. The dotted horizontal lines indicate the reference interval $(2.5 \%$ lower limit $=0.24 \mathrm{mmol} / \mathrm{L}$ and $97.5 \%$ upper limit $=0.49 \mathrm{mmol} / \mathrm{L}$ ) from a physically active population. (B.) Uric acid percentage change between successive pairs of serial results for the soccer players during a season of training/competition. The dotted horizontal lines indicate the RCV95\% for uric acid $=35.0 \%$

While there were no significant changes in the serial results during the season (Figure 2B), three players were determined to be below the lower reference interval (Figure 2A). 


\section{Discussion}

This study is the first to test the applicability of reference intervals and the RCV values obtained from physically active individuals (Nunes \& Macedo, 2008; Nunes et al., 2010) in longitudinally monitoring the effects of training/competition on soccer players.

The players analyzed in this study were from the under-20 category. During the competition season (14 weeks), the games occurred on Saturday mornings. All players, including the outfield players, were submitted to a daily game-based training, where modified games are played on reduced pitch areas, often using adapted rules and involving a smaller number of players than in traditional soccer games. Different small-sided game designs were used during the season to improve specific physical capacities (e.g., sprint, speed, aerobic) (HillHaas et al., 2011). An important observation emerging from our data is that all of the soccer players supported this type of training very well for the entire season, including the competitions schedule, as the majority of the alterations shown here were within the reference interval for all of the analytes.

On the other hand, the comparison of serial analyses with RCV values increased the sensitivity and specificity of some analytes as biomarkers of individual training effects. From 56 players, only 17 and 15 exhibited significant alterations in a biochemical analyte or hemogram parameter, respectively, at any time point (Table 3 and 4). Knowledge of the RCV values permits an individual response to those subjects who exceed the percentage of alteration at one or more blood analyses as compared to previous analyses; these subjects can undergo a closer follow up daily or weekly, contributing to the individual adjustment of the training intensity, improvement of nutritional interventions and prevention of stress overload.

For example, the athletes 14 and 19 (Table 3 and 4) were submitted to the same training load and competitions and showed significant increases in the levels of their CK, leukocytes and neutrophils after three months. Although only the neutrophils showed changes that were above the reference interval, this set of changes may be related to a higher inflammatory response and muscle damage after this period of training and competitions, which can lead to an acute deterioration in performance (Ispirlidis et al., 2008). Note that athlete 35 at C3 also exhibited a $\triangle C K$ that was higher than the RCV $(119.8 \%)$, but no other parameters were altered. Additionally, the absolute value was lower than that for athletes 14 and 19 . It is likely that the higher $\Delta \mathrm{CK}$ for this player merely indicated a higher participation in the training schedule. This information can therefore be useful to help the coach plan for adequate recovery time for just those athletes, especially if they are competing players. This information can also be useful to the nutritionist in individually adjusting some nutrients to improve the recovery rate between training sections and games, preserving these athletes.

An interesting point observed here is that after the first month of training, 8 athletes showed significant changes in their serum urea when compared to RCV values. This result may indicate a continuous catabolic state at the beginning of competitions (Hartmann \& Mester, 2000). It is not unusual that soccer players present with an inadequate ingestion of carbohydrates because of a low energy intake or a high fat and protein intake (Garrido et al., 2007). As this macronutrient is important in preserving muscle mass, an inadequate ingestion can lead some athletes to a catabolic state that can impair their performance if not corrected. Thus, these 8 athletes could undergo a specific nutritional intervention.

The time point (C3) showed a higher number of positive training adaptations in the majority of the players. The serum creatinine values were significantly higher than the RCV values for five players, which could indicate a muscular mass gain in these subjects at the 
beginning of the competitions. In addition to creatinine, the hemoglobin concentrations increased significantly at C3, mainly in the athletes with levels near the lower limit of the population-based reference interval, indicating a positive training adaptation that is related to $\mathrm{O}_{2}$ transport, such as increasing the plasma volume and the erythrocyte number (Sawka et al., 2000; Convertino, 2007). Only athlete 23 must be followed more carefully after C4 due to a significant decrease in the $\mathrm{Hb}$ concentration as compared to $\mathrm{C} 3$. This decrease can also be influenced by nutritional status, such as an inadequate intake of minerals like iron, zinc, copper, folic acid and complex B vitamins (Lukaski, 2004).

In this study we have also shown the need for a comparison of results with reference intervals that were established from a physically active population. For example, all of the players exhibited serum urate concentrations that were within the RCV values (Figure 2B), but three athletes exhibited values below the $2.5 \%$ percentile (Figure $2 \mathrm{~A}$ ). As uric acid is one of the most important plasma antioxidants (Lippi et al., 2008) this result could indicate a lower capacity of defense against ROS. The nutritionist could individually improve the antioxidant content of the diet, offering to these athletes more vegetables and fruits rich in this nutrient. This simple intervention may increase plasma antioxidant levels (Brevik et al., 2004).

\section{Conclusions}

The data presented here point to the Reference Interval and the RCV as important tools for the correct interpretation of the results proceeding from blood analyses related to the monitoring of athletes' training. Advances in analytical technology, such as proteomic analysis, may present new information concerning the athlete's protein and metabolic profile. These methods must also have their reference intervals and RCVs determined for effective for sport science application, providing coaches and interdisciplinary teams with the ability to make individual, punctual interventions that could make a difference in the continuous adaptive processes of all athletes throughout the season.

\section{Acknowledgments}

The authors thank the voluntary research subjects, Cristian Ramirez (Paulinia Futebol Clube coach) and the Commander of the Military Army, who permitted this study. We would also like to thank Ana Porto, Mauro Pascoa, Madla Adami dos Passos and Lucas Samuel Tessuti for their assessment of the given technique. This study was supported by the University Foundation (Funcamp-Conv927.7-BIO0100). Lázaro Alessandro S. Nunes and Fernanda Lorenzi Lazarim received scholarships from Brazilian agencies CNPq and CAPES, respectively.

\section{References}

Banfi, G. \& Del Fabro, M. (2006). Relation between serum creatinine and body mass index in elite athletes of different sport disciplines. Br J Sports Med, Vol.40, No.8 (Aug), pp.675-678, ISSN 0306-3674.

Banfi, G. \& Dolci, A. (2003). Preanalytical phase of sport biochemistry and haematology. J Sports Med Phys Fitness, Vol.43, No.2 (Jun), pp.223-230, ISSN 0022-4707

Banfi, G., Del Fabbro, M. \& Lippi, G. (2009). Serum creatinine concentration and creatininebased estimation of glomerular filtration rate in athletes. Sports Med, Vol.39, No.4, pp.331-337, ISSN 0112-1642 
Bangsbo, J. (1994). The physiology of soccer-with special reference to intense intermittent exercise. Acta Physiot Scand, Vol.151, No.suppl 619, pp.1-156, ISSN 0302-2994

Bangsbo, J., Mohr, M. \& Krustrup, P. (2006). Physical and metabolic demands of training and match-play in the elite football player. J Sports Sci, Vol.24, No.7 (Jul), pp.665674, ISSN 0264-0414

Brancaccio, P., Lippi, G. \& Maffulli, N. (2010). Biochemical markers of muscular damage. Clin Chem Lab Med, Vol.48, No.6 (Jun), pp.757-767, ISSN 1434-6621

Brancaccio, P., Maffulli, N., Buonauro, R. \& Limongelli, F. M. (2008). Serum enzyme monitoring in sports medicine. Clin Sports Med, Vol.27, No.1 (Jan), pp.1-18, ISSN 1556-228X

Brevik, A., Andersen, L.F., Karlsen, A., Trygg, K.U., Blomhoff, R. \& Drevon, C.A. (2004). Six carotenoids in plasma used to assess recommended intake of fruits and vegetables in a controlled feeding study. Eur J Clin Nutr, Vol.58, No.8 (Aug), pp.1166-1173, ISSN 0954-3007.

Butterfield, T.A., Best, T.M. \& Merrick, M.A. (2006). The dual roles of neutrophils and macrophages in inflammation: a critical balance between tissue damage and repair. J Athl Train, Vol.41, No.4 (Oct-Dec), pp.457-465, ISSN 1062-6050

Carlsohn, A., Rohn, S., Bittmann F., Raila, J., Mayer, F. \& Schweigert, F.J. (2008). Exercise increases the plasma antioxidant capacity of adolescent athletes. Ann Nutr Metab, Vol.53, No.2, pp.96-103, ISSN 1421-9697

Catanho da Silva, F.O. \& Macedo, D.V. (2011). Physical exercise, inflammatory process and adaptive condition: an overview. Braz. J. Kinanthropometry and Human Performance. Vol.13, No.4, pp.320-328, ISSN 1415-8426.

Cervellin, G., Comelli, I. \& Lippi, G. (2010). Rhabdomyolysis: historical background, clinical, diagnostic and therapeutic features. Clin Chem Lab Med, Vol.48, No.6 (Jun), pp.749756, ISSN 1434-6621

Chatzinikolaou, A., Fatouros, I. G., Gourgoulis, V., Avloniti, A., Jamurtas, A. Z., Nikolaidis, M. G., Douroudos, I., Michailidis, Y., Beneka, A., Malliou, P., Tofas, T., Georgiadis, I., Mandalidis, D. \& Taxildaris, K. (2010). Time course of changes in performance and inflammatory responses after acute plyometric exercise. J Strength Cond Res, Vol.24, No.5 (May), pp.1389-1398, ISSN 1533-4287

Clarkson, P.M. \& Ebbeling, C. (1988). Investigation of serum creatine kinase variability after muscle-damaging exercise. Clin Sci, Vol.75, No.3 (Sep), pp.257-261, ISSN 0143-5221

Convertino, V.A. (2007). Blood volume response to physical activity and inactivity. Am J Med Sci, Vol.334, No.1 (Jul), pp.72-79, ISSN 0002-9629

Eliakim, A., Nemet, D. \& Shenkman, L. (1995). Serum enzyme activities following longdistance running: comparison between Ethiopian and white athletes. Isr J Med Sci, Vol.31, No.11 (Nov), pp.657-659, ISSN 0021-2180

Fatouros, I. G., Chatzinikolaou, A., Douroudos, I. I., Nikolaidis, M. G., Kyparos, A., Margonis, K., Michailidis, Y., Vantarakis, A., Taxildaris, K., Katrabasas, I., Mandalidis, D., Kouretas, D. \& Jamurtas, A. Z. (2010). Time-course of changes in oxidative stress and antioxidant status responses following a soccer game. J Strength Cond Res, Vol.24, No.12(Dec), pp.3278-3286, ISSN 1533-4287

Fielding, R. A., Manfredi, T. J., Ding, W., Fiatarone, M. A., Evans, W. J. \& Cannon, J. G. (1993). Acute phase response in exercise. III. Neutrophil and IL-1 beta accumulation in skeletal muscle. Am J Physiol, Vol.265, No.1 (Jul), pp.R166-172, ISSN 0002-9513 
Finaud, J., Lac, G. \& Filaire, E. (2006). Oxidative Stress. Relationship with exercise and training. Sports Med, Vol.36, No.4, pp.327-358, ISSN 0112-1642

Fraser, C.G. \& Harris, E.K. (1989). Generation and application of data on biological variation in clinical chemistry. Crit Rev Clin Lab Sci, Vol.27, No.5, pp.409-437, ISSN 0112-1642

Fraser, C.G. \& Petersen, P.H. (1999). Analytical performance characteristics should be judged against objective quality specifications. Clin Chem, Vol.45, No.3 (Mar), pp.321-323, ISSN 0009-9147

Fraser, C.G. (2004). Inherent biological variation and reference values. Clin Chem Lab Med, Vol.42, No.7 (Jul), pp.758-764, ISSN 1434-6621

Fraser, CG. (2001). Changes in the serial results, In: Biological variation: from principles to practice, pp. 67-90, ISBN 1-890883-49-2, AACC Press, Washington DC

Garrido, G., Webster, A. L. \& Chamorro, M. (2007). Nutritional Adequacy of different Menu Settings in Elite Spanish Adolescent Soccer Players. Int J Sport Nutr Exerc Metab, Vol.17, No.5(Oct), pp.421-432, ISSN 1526-484X

Gilligan, D. R., Altschule, M. D. \& Katersky, E. M. (1943). Physiological intravascular hemolysis of exercise hemoglobinemia and hemoglobinuria following crosscountry runs. J Clin Invest, Vol.22, No.6 (Nov), pp.859-869, ISSN 0021-9738

Gleeson, M. (2006). Immune system adaptation in elite athletes. Curr Opin Clin Nutr Metab Care, Vol.9, No.6 (Nov), pp. 659-665, ISSN 1363-1950

Gleeson, M. (2007). Immune function in sport and exercise. J Appl Physiol, Vol.103, No.2 (Aug), pp.693-699, ISSN 8750-7587

Gruys, E., Toussaint, M. J., Niewold, T. A. \& Koopmans, S. J. (2005). Acute phase reaction and acute phase proteins. Journal of Zhejiang University. Science. B, Vol.6, No.11(Nov), pp. 1045-1056, ISSN 1673-1581

Harris, E.K. \& Yasaka, T. (1983). On the calculation of a "reference change" or comparing two consecutive measurements. Clin Chem, Vol.29, No.1(Jan), pp.25-30, ISSN 0009-9147

Hartmann, U. \& Mester, J. (2000). Training and overtraining markers in selected sport events. Med. Sci. Sports Exerc, Vol.32, No.1 (Jan), pp.209-215, ISSN 0195-9131

Hawley, J.A., Tipton, K.D. \& Millard-Stafford, M.L. (2006). Promoting training adaptations through nutritional interventions. Journal of Sports Sciences, Vol.24, No.7 (Jul), pp.709-721, ISSN 0264-0414

Hawley, JA., Burke, LM., Phillips, SM. \& Spriet, LL. (2011). Nutritional modulation of traininginduced skeletal muscle adaptations. J Appl Physiol, Vol.110, No.3 (March), pp. 834-845.

Hill-Haas, S.V., Dawson, B., Impellizzeri, F.M. \& Coutts, A.J. (2011). Physiology of smallsided games training in football: a systematic review. Sports Med, Vol.41, No.3 (Mar), pp.199-220, ISSN 0112-1642.

Hohl, R., Ferraresso, RLP., Oliveira, RB., Lucco, R., Brenzikofer, R., \& Macedo, DV. (2009). Development and characterization of an overtraining animal model. Med. Sci. Sports Exerc, Vol.41, No. 5 (May), pp. 1155-1163, ISSN 1530-0315

Horn, P.S., Feng, L., Li, Y., \& Pesce, A.J. (2001). Effect of outliers and nonhealthy individuals on reference interval estimation. Clin Chem, Vol.47, No 12 (Dec), pp. 2137-2145, ISSN 0009-9147

Ispirlidis, I., Fatouros, I. G., Jamurtas, A.Z., Nikolaidis, M.G., Michailidis, I., Douroudos, I., Margonis, K., Chatzinikolaou, A., Kalistratos, E., Katrabasas, I., Alexiou, V. \& Taxildaris, K. (2008). Time-course of changes in inflammatory and performance 
responses following a soccer game. Clin J Sport Med, Vol.18, No.5 (Sep), pp. 423-31, ISSN 1536-3724

Ji, L.L. (1999). Antioxidants and oxidative stress in exercise. Proc Soc Exp Biol Med, Vol.222, No.3 (Dec), pp.283-292, ISSN 0037-9727

Kasapis, C. \& Thompson, P. D. (2005). The effects of physical activity on serum C-reactive protein and inflammatory markers: a systematic review. J Am Coll Cardiol,Vol.45, No.10 (May), pp.1563-1569, ISSN 0735-1097

Kjeldsberg, C. (1992). Normal Values of blood and bone marrow in human, In: Wintrobe's Hematology Clinical Hematology, T.C. Bithell, J. Forester, J.W. Athens, J.N. Lukens \& J. Kushner, pp.2531-2543, Lea \& Febinger, Philadelphia

Lac, G. \& Maso F. (2004). Biological markers for the follow-up of athletes throughout the training season. Pathol Biol, Vol.52, No.1(Feb), pp. 43-49, ISSN 0369-8114

Lazarim, F.L., Antunes-Neto, J.M.F., Oliveira da Silva, F.C., Nunes, L.A.S., Cameron, A.B., Cameron, L.C., Alves, A.A., Brenzikofer, R., \& Macedo, D.V. (2009). The upper values of creatine kinase of professional soccer players during a Brazilian national championship. J Sci Med Sport. Vol.12, No. 1 (Jan), pp. 85-90, ISSN 1440-2440.

Lehmann, M., Foster, C., Dickhuth, H. H. \& Gastmann, U. (1998) Autonomic imbalance hypothesis and overtraining syndrome. Med Sci Sports Exerc, Vol.30, No.7 (Jul), pp.1140-1145, 0195-9131

Lippi, G., Montagnana, M., Franchini M, Favaloro, E. J. \& Targher, G. (2008). The paradoxical relationship between serum uric acid and cardiovascular disease. Clin Chim Acta, Vol.392, No.1-2 (Jun), pp.1-7, ISSN 0009-8981

Lira, F.S., Rosa J.C., Yamashita, A.S., Koyama, C.H., Batista Jr, M.L. \& Seelaender M. (2009). Endurance training induces depot-specific changes in IL-10/TNF-a ratio in rat adipose tissue. Cytokine, Vol.45, No.2 (Feb), pp.80-85, ISSN 1096-0023

Lukaski, H.C. (2004). Vitamin and Mineral Status: Effects on Physical Performance. Nutrition, Vol.20, No.7-8 (Jul-Aug 2004), pp.632-644, ISSN 0899-9007

Malm, C. (2001). Exercise-induced muscle damage and inflammation: fact or fiction? Acta Physiol Scand, Vol.171, No.3 (Mar), pp.233-239, ISSN 0001-6772

Manfredi, T. G., Fielding, R. A., O'Reilly, K. P., Meredith, C. N., Lee, H. Y. \& Evans, W. J. (1991). Plasma creatine kinase activity and exercise-induced muscle damage in older men. Med Sci Sports Exerc, Vol.23, No.9 (Sep), pp.1028-1034, ISSN 0195-9131

McNeil, P.L. \& Khakee, R. (1992). Disruptions of muscle fiber plasma membranes. Role in exercise-induced damage. Am J Pathol, Vol.140, No.5 (May), pp.1097-1109, ISSN 0002-9440

Nordin, G., Mårtensson, A., Swolin, B., Sandberg, S., Christensen, N. J., Thorsteinsson, V., Franzson, L., Kairisto, V. \& Savolainen, E. R. (2004). A multicentre study of reference intervals for haemoglobin, basic blood cell counts and erythrocyte indices in the adult population of the Nordic countries. Scand J Clin Lab Invest, Vol.64, No.4, pp. 385-98, ISSN 0036-5513

Nunes, L.A.S. \& Macedo, D.V. (2008). Reference intervals for biochemical parameters in physically active young men. Clin Chem Lab Med, Vol.46 (Aug), pp.S1-S859, ISSN 1434-6621

Nunes, LAS., Brenzikofer, R., \& Macedo, DV. (2010). Reference change values of blood analytes from physically active subjects. Eur J Appl Physiol, Vol. 110, No.1 (Sep), pp. $191-198,1439-6327$ 
Pattwell, D.M., McArdle, A., Morgan, J.E., Jackson, M. J.Patridge, T.A. (2004). Release of reactive oxygen and nitrogen species from contracting skeletal muscle cells. Free Radic Biol Med, Vol.37, No.7 (Oct), pp.1064-1072, 0891-5849

Peake, J.M., Suzuki, K. \& Coombee JS. (2007). The influence of antioxidant supplementation on markers of inflammation and relationship to oxidative stress after exercise. $J$ Nutr Biochem, Vol.18, No.6 (Jun), PP.357-371, ISSN 0955-2863

Pedersen B.K., Rohde T.M. \& Ostrowski K. (1998). Recovery of the immune system after exercise. Acta Physiol Scand. Vol.162, pp.325-32 ISSN 0001-6772.

Pedersen, B.K. \& Hoffman-Goetz, L. (2000). Exercise and the immune system: regulation, integration, and adaptation. Physiol Rev, Vol.80, No.3 (Jul), pp.1055-1081, ISSN 0031-9333

Pedersen, B.K., Rohde, T. \& Ostrowski, K. (1998). Recovery of the immune system after exercise. Acta Physiol Scand, Vol.162, No.3 (Mar), pp.325-332, ISSN 0001-6772

Perrone, R.D., Madias, N.E. \& Levey, A.S. (1992). Serum creatinine as an index of renal function: new insights into old concepts. Clin Chem. Vol.38, No.10 (Oct), pp.19331953, ISSN 0009-9147

Petersen, A.M.W. \& Pedersen, B.K. (2005). The anti-inflammatory effect of exercise. J Appl Physiol, Vol.98, No.4 (Apr), pp.1154-1162, ISSN 8750-7587

Petersen, P.H. (2005). Making the most of a patient's laboratory data: optimisation of signalto-noise ratio. Clin Biochem Rev, Vol.26. No.4(Nov), pp.91-96, ISSN 0159-8090

Petersen, P.H., Fraser, C.G., Sandberg, S. \& Goldschmidt, H. (1999). The index of individuality is often a misinterpreted quantity characteristic. Clin Chem Lab Med, Vol.37, No.6 (Jun), p.655-661, ISSN 1434-6621

Pyne, D.B. (1994). Regulation of neutrophil function during exercise. Sports Med, Vol.17, No.4(Apr), pp.245-258, ISSN 0112-1642

Reilly, T. (1997). Energetics of high-intensity exercise (soccer) with particular reference to fatigue. J Sports Sci, Vol.15, No.3(Jun), pp.257-263, ISSN 0264-0414

Ricós, C., Alvarez, V., Cava, F., García-Lario, J.V., Hernández, A., Jiménez, C.V.,Minchinela, J., Perich, C. \& Simón, M. (1999). Current databases on biologic variation: pros, cons and progress. Scand J Clin Lab Invest, Vol.59, No.7 (Nov), pp.491-500, ISSN 0036-5513

Ricós, C., Cava, F., Garcia-Lario, J.V., Hernández, A., Iglesias, N., Jiménez, C.V., Minchinela, J., Perich, C., Simón, M., Domenech, M.V. \& Alvarez, V. (2004). The reference change value: a proposal to interpret laboratory reports in serial testing based on biological variation. Scand J Clin Lab Invest, Vol.64, No.3, pp.175-184, ISSN 0036-5513

Rowbottom, D.G. \& Green, K.J. (2000). Acute exercise effects on the immune system. Med Sci Sports Exerc, Vol.32, No.7(Jul), pp.S396-S405, ISSN 0195-9131

Rustad, P., Felding, P., Franzson, L., Kairisto, V., Lahti, A., Mårtensson, A., Hyltoft Petersen, P., Simonsson, P., Steensland, H. \& Uldall, A. (2004). The Nordic Reference Interval Project 2000: recommended reference intervals for 25 common biochemical properties. Scand J Clin Lab Invest, Vol.64, No.4, pp.271-284, ISSN 0036-5513

Sawka, M.N., Convertino, V.A., Eichner, R., Schinieder, S.M., \& Young, A.G. (2000). Blood volume: importance and adaptations to exercise training, environmental stresses, and trauma/sickness. Med Sci Sports Exerc, Vol. 32, No.2 (Feb), pp. 332-348, ISSN 0195-9131

Sayers, S.P. \& Clarkson, P.M.(2003). Short-term immobilization after eccentric exercise. Part II: creatine kinase and myoglobin. Med Sci Sports Exerc, Vol.35, No.5 (May), pp.762768, ISSN 0195-9131 
Schumacher, Y.O., Schmid, A., Grathwohl, D., Bültermann, D. \& Berg, A. (2002). Hematological indices and iron status in athletes of various sports and performances. Med. Sci. Sports Exerc, Vol.34, No.5 (May), pp.869-875, ISSN 0195-9131

Serrão, F.V., Foerster, B., Spada, S., Morales, M.M., Monteiro-Pedro, V., Tannu's, A. \& Salvini, T. F. (2003). Functional changes of human quadriceps muscle injured by eccentric exercise. Braz J Med Biol Res, Vol.36, No.6(Jun), pp.781-786, 0100-879X

Smith, J.A. (1995). Exercise, training and red blood cell turnover. Sports Med, Vol.19, No.1(Jan), pp.9-31, ISSN 0112-1642.

Smith, L.L. (2000). Cytokine hypothesis of overtraining: a physiological adaptation to excessive stress? Med Sci Sports Exerc, Vol. 32, No.2 (Feb), pp.317-331, ISSN 1522-1601

Solberg, H.E. (2004). The IFCC recommendations on estimation of reference intervals. The RefVal Program. Clin Chem Lab Med, Vol.42, No.7 (Jul), pp. 710-714, ISSN 1434-6621

Sottas, P.E., Robinson, N. \& Saugy, M. (2010). The athlete's biological passport and indirect markers of blood doping. Handb Exp Pharmacol. Vol.195, pp305-326, ISSN 0171-2004

Steensberg, A., van Hall, G., Osada, T., Sacchetti, M., Saltin, B. \& Pedersen, K.B. (2000). Production of interleukin-6 in contracting human skeletal muscles can account for the exercise-induced increase in plasma interleukin-6. J Physiol, Vol. 529, Pt 1 (Nov), pp.237-242, ISSN 0022-3751

Telford, R. D., Sly, G. J., Hahn, A. G., Cunningham, R. B., Bryant, C. \& Smith, J. A. (2003). Footstrike is the major cause of hemolysis during running. J Appl Physiol, Vol.94, No.1(Jan), pp.38-42, ISSN 8750-7587

Tidball J.G. (2005a) Mechanical signal transduction in skeletal muscle growth and adaptation. J Appl Physiol, 98(5):1900-8.

Tidball, J.G. (2005b). Inflammatory processes in muscle injury and repair. Am J Physiol Regul Integr Comp Physiol, Vol.288, No.2(Feb), R345-353, ISSN 0363-6119

Tiidus, P.M. (2000). Estrogen and gender effects on muscle damage, inflammation and oxidative stress. Can J Appl Physiol, Vol.25, No.4 (Aug), pp274-287, ISSN 1066-7814

Toumi, H. \& Best, T.M. (2003). The inflammatory response: friend or enemy for muscle injury? Br J Sports Med, Vol.37, No.4 (Aug), pp.284-286, ISSN 0306-3674

Urhausen, A. \& Kindermann, W. (2002). Diagnosis of Overtraining. What Tools Do We Have? Sports Med, Vol.32, No. 2, pp.95-102, ISSN 0112-1642

Weight, L.M., Byrne, M. J. \& Jacobs, P. (1991). Haemolytic effects of exercise. Clin Sci (Lond), Vol.81, No.2 (Aug), pp.147-152, ISSN 0143-5221.

Westgard, J.O. (2004). Design of internal quality control for reference value studies. Clin Chem Lab Med, Vol.42, No.7 (Jul), pp. 863-867, ISSN 1434-6621

Wu, A.H.B., Smith, A. \& Wians, F. (2009). Interpretation of creatine kinase and aldolase for statin-induced myopaty: Reliance on serial testing based on biological variation. Clin Chim Acta, Vol.399, No1-2(Jan), pp.109-111, ISSN 1873-3492

Youssef, H., Groussard, C., Machefer, G., Minella, O., Couillard, A., Knight, J. \& GratasDelamarche, A. (2008). Comparison of total antioxidant capacity of salivary, capillary and venous samplings: interest of the salivary total antioxidant capacity on triathletes during training season. J Sports Med Phys Fitness, Vol.48, No.4 (Dec), pp.522-529, ISSN 0022-4707

Zoller, H. \& Vogel, W. (2004). Iron supplementation in athletes--first do no harm. Nutrition, Vol.20, No.7-8 (Jul-Aug), pp.615-619, ISSN 0899-9007 


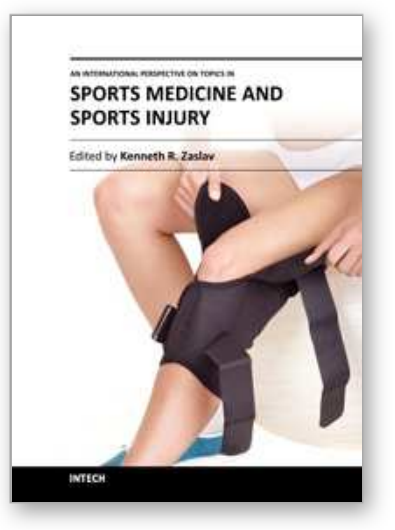

\author{
An International Perspective on Topics in Sports Medicine and \\ Sports Injury \\ Edited by Dr. Kenneth R. Zaslav
}

ISBN 978-953-51-0005-8

Hard cover, 534 pages

Publisher InTech

Published online 17, February, 2012

Published in print edition February, 2012

For the past two decades, Sports Medicine has been a burgeoning science in the USA and Western Europe. Great strides have been made in understanding the basic physiology of exercise, energy consumption and the mechanisms of sports injury. Additionally, through advances in minimally invasive surgical treatment and physical rehabilitation, athletes have been returning to sports quicker and at higher levels after injury. This book contains new information from basic scientists on the physiology of exercise and sports performance, updates on medical diseases treated in athletes and excellent summaries of treatment options for common sports-related injuries to the skeletal system.

\title{
How to reference
}

In order to correctly reference this scholarly work, feel free to copy and paste the following:

Lázaro Alessandro Soares Nunes, Fernanda Lorenzi Lazarim, René Brenzikofer and Denise Vaz Macedo (2012). Applicability of the Reference Interval and Reference Change Value of Hematological and Biochemical Biomarkers to Sport Science, An International Perspective on Topics in Sports Medicine and Sports Injury, Dr. Kenneth R. Zaslav (Ed.), ISBN: 978-953-51-0005-8, InTech, Available from: http://www.intechopen.com/books/an-international-perspective-on-topics-in-sports-medicine-and-sportsinjury/applicability-of-the-reference-interval-and-reference-change-value-of-hematological-and-biochemical-

\section{INTECH}

open science | open minds

\author{
InTech Europe \\ University Campus STeP Ri \\ Slavka Krautzeka 83/A \\ 51000 Rijeka, Croatia \\ Phone: +385 (51) 770447 \\ Fax: +385 (51) 686166 \\ www.intechopen.com
}

\author{
InTech China \\ Unit 405, Office Block, Hotel Equatorial Shanghai \\ No.65, Yan An Road (West), Shanghai, 200040, China \\ 中国上海市延安西路65号上海国际贵都大饭店办公楼 405 单元 \\ Phone: +86-21-62489820 \\ Fax: +86-21-62489821
}


(C) 2012 The Author(s). Licensee IntechOpen. This is an open access article distributed under the terms of the Creative Commons Attribution 3.0 License, which permits unrestricted use, distribution, and reproduction in any medium, provided the original work is properly cited. 